\title{
Human Infection with Orf Virus and Description of Its Whole Genome, France, 2017
}

\author{
Julien Andreani, Jessica Fongue, Jacques Y. Bou Khalil, Laurene David, Saïd Mougari, \\ Marion Le Bideau, Jonatas Abrahão, Philippe Berbis, Bernard La Scola
}

\begin{abstract}
Zoonotic transmission of parapoxvirus from animals to humans has been reported; clinical manifestations are skin lesions on the fingers and hands after contact with infected animals. We report a human infection clinically suspected as being ecthyma contagiosum. The patient, a 65 -year-old woman, had 3 nodules on her hands. She reported contact with a sheep during the Aïd-el-Fitr festival in France during 2017. We isolated the parapoxvirus orf virus from these nodules by using a nonconventional cell and sequenced the orf genome. We identified a novel orf virus genome and compared it with genomes of other orf viruses. More research is needed on the genus Parapoxvirus to understand worldwide distribution of and infection by orf virus, especially transmission between goats and sheep.
\end{abstract}

P arapoxvirus is a genus of double-stranded DNA viruses (family Poxviridae) that contains 4 virus species: orf virus, bovine papular stomatitis virus, parapoxvirus of red deer, and pseudocowpoxvirus. Recently, a complete genome from a gray seal infected by a parapoxvirus was reported and constituted a putative novel virus in this genus (1). Zoonotic transmission of parapoxvirus from animals to humans has been reported in the past few decades; the main human clinical manifestations are skin lesions on the fingers and hands after contact with infected animals (2-5).

Most human cases of infection with parapoxvirus reported are caused by orf virus $(2,6,7)$, but some human infections are caused by pseudocowpoxviruses $(8,9)$. Infection of small ruminants with orf virus is frequent and widely distributed worldwide. Orf virus disease is also known as contagious ecthyma, scabby mouth, sore mouth, or infectious pustular dermatitis. Humans can be infected

Author affiliations: Institut Hospitalo-Universitaire Méditerranée Infection, Marseille, France (J. Andreani, J.Y. Bou Khalil,

S. Mougari, M. Le Bideau, B. La Scola); Centre Hospitalier Universitaire Hôpital Nord, Marseille (J. Fongue, L. David,

P. Berbis); Universidade Federal de Minas Gerais, Belo Horizonte, Brazil (J. Abrahão)

DOI: https://doi.org/10.3201/eid2512.181513 with orf virus by contact with sheep and goats during religious or cultural practices and during slaughter of animals $(4,10)$, and infections appear to be more frequent during the last 3 months of each year (3). Human-to-human infection is extremely rare $(11,12)$. Vaccination against orf virus is available for animals, although it does not confer long-term protective immunity (13). Human infections are relatively frequent when populations are exposed to sheep and goats (occupational disease). However, complete genomes of orf viruses are rarely found in public databases, which results in limited comparative studies in this field.

Diagnosis of human infections with orf virus is usually made by histologic analysis, molecular biology (PCR) studies, or electron microscopy. At least 11 complete orf virus genomes are available, and at least 19 are available for the entire genus Parapoxvirus. Nevertheless, a unique orf virus was sequenced after a human case report (14) (orf virus strain B029). These data are in contrast with those for orthopoxviruses (another Poxviridae genus) in which $>300$ genomes are available. One of the reasons for limited availability of parapoxvirus genomes is that many of these viruses are not cultivable on most diagnostic laboratories' cell lines (15).

In 2017, we identified a 65-year-old woman in France who had 3 nodules on her hands. She was given a diagnosis of ecthyma contagiosum. Genomic and electron microscopy data confirmed the initial diagnosis as infection with orf virus and identified this virus as the etiologic agent. We also isolated this virus on OA3.Ts cells.

\section{Materials and Methods}

\section{Case-Patient}

A 65-year-old woman came to North Hospital (Marseille, France) because of 3 nodules on her hands. She reported contact 3 weeks earlier with the carcass of a dead sheep during the Aïd-el-Fitr festival (June 25, 2017) in the Bouches-du-Rhones Department in southern France. Clinically, she had 3 painless, well-delimited erythematosus nodules on her fingers with an erythematosus halo (Figure 1). On 

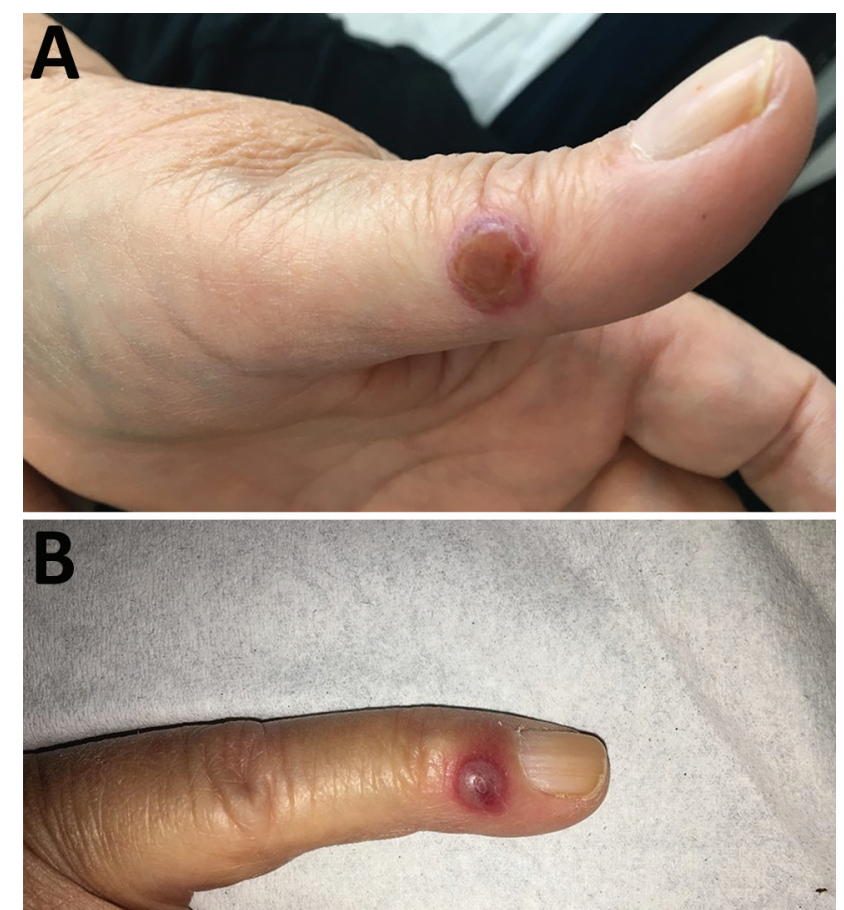

Figure 1. Nodules on the A) left thumb and B) left little finger of a 65-year-old woman infected with orf virus during Aïd-el-Fitr festival, France, 2017.

the basis of clinical suspicion of ecthyma contagiosum, we obtained a cutaneous biopsy specimen for biologic confirmations by PCR and histologic analysis. Histopathologic analysis of the skin biopsy specimen showed a moderate epidermal hyperplasia, spongiform degeneration with vacuolated cells, and inflammatory infiltration into the dermis (Figure 2). The patient was given antiseptic and local antimicrobial drug therapy ( $2 \%$ fusidic acid cream) to prevent bacterial superinfection. All skin lesions healed in 3 weeks.

\section{Virus Detection, Isolation, and Production}

We performed a parapoxvirus PCR on the cutaneous biopsy sample by using primers forward 5'-CGGTGCAGCACGAGGTC-3', reverse 5'-CGGCGTATTCTTCTCGGACT-3', and 6FAM-5'-GCCTAGGAAGCGCTCCGGCG-3'. These primers are specific for the $\mathrm{B} 2 \mathrm{~L}$ gene, which encodes the major membrane protein of parapoxvirus.

For virus culture, we crushed a biopsy sample and resuspended it in Hanks' balanced salt solution (Thermo Fisher Scientific, https://www.thermofisher.com). We then inoculated $400 \mu \mathrm{L}$ of this sample onto 2 shell vials $(200 \mu \mathrm{L} /$ vial) (7-mL TRAC bottles; Thermo Fisher Scientific) containing $1 \mathrm{~mL}$ of OA3.Ts testes cells from Ovis aries sheep (CRL-6546; American Type Culture Collection, https:// www.atcc.org) at a concentration of $10^{6}$ cells $/ \mathrm{mL}$. We incubated 1 vial at $32^{\circ} \mathrm{C}$ and 1 vial at $37^{\circ} \mathrm{C}$ in an atmosphere of $5 \% \mathrm{CO}_{2}$ and observed daily by inverted microscopy to detect any potential cytopathic effect.
For virus production, we prepared 15 flasks $\left(\mathrm{T} 75 \mathrm{~cm}^{2}\right.$; Corning, https://www.corning.com) containing OA3.Ts cells and Dulbecco's modified Eagle medium (Thermo Fisher Scientific) plus 10\% fetal bovine serum and 1\% glutamine. We then incubated the cells, and when they reached a confluence of $80 \%$ of confluence, we removed the medium and inoculated the monolayer with $5 \mathrm{~mL}$ of virus suspension at a multiplicity of infection of 0.01 . We incubated the flasks at $37^{\circ} \mathrm{C}$ for $1 \mathrm{~h}$ to enable adsorption. We then added $20 \mathrm{~mL}$ of Dulbecco's modified Eagle medium to the flasks and incubated them for 3 days. On the third day, we discarded the supernatant, washed the cell monolayer 3 times with phosphate-buffered saline, and removed the monolayer by using a scraper. Once all the flasks were scraped and washed twice to collect cells, we transferred all contents to a $50-\mathrm{mL}$ tube and kept the tube on ice.

We then centrifuged the cells at $500 \times g$ for $10 \mathrm{~min}$, removed the supernatant, resuspended the pellet in $10 \mathrm{~mL}$ of sterile lysis buffer $\left(1 \mathrm{mmol} / \mathrm{L} \mathrm{MgCl}_{2}, 10 \mathrm{mmol} / \mathrm{L}\right.$ Tris, and $10 \mathrm{mmol} / \mathrm{L} \mathrm{KCl}, \mathrm{pH} \mathrm{7.0)}$, and incubated this suspension for $10 \mathrm{~min}$ on ice. We performed mechanical lysis by using a sterile douncer device ( 80 cycles on ice). In parallel, we filtered the entire supernatant by using a $0.45-\mu \mathrm{m}$ polyvinylidene difluoride membrane (Dutscher, https://www. dutscher.com) and centrifuged the supernatant. Finally, we added $10 \mathrm{~mL}$ of $25 \%$ sucrose to a plastic centrifugation tube, and slowly transferred the virus mixture from the filtrate to avoid mixing with the sucrose solution (biphasic final solution). We centrifuged the tube at $60,000 \times g$ for 1 $\mathrm{h}$ at $4^{\circ} \mathrm{C}$, collected the pellet, and stored the pellet at $-80^{\circ} \mathrm{C}$ in small aliquots before genome sequencing.

\section{Sample Embedding and Cell Preparation}

We maintained OA3.Ts cells in culture containing minimal essential medium plus $10 \%$ fetal bovine serum. We inoculated the cell monolayer with parapoxvirus at a multiplicity of infection of 0.01 and incubated. We then collected the contents after scraping the flask $\left(\mathrm{T}-25 \mathrm{~cm}^{2}\right)$ at 24 $\mathrm{h}$ postinfection.

We used the protocol of cell embedding as described in Bou Khalil et al. (16). We replaced the Epon resin with LR White resin (Agar Scientific, http://www.agarscientific. com). In brief, we fixed cells for $1 \mathrm{~h}$ with $2.5 \%$ glutaraldehyde in a $0.1 \mathrm{~mol} / \mathrm{L}$ sodium cacodylate buffer and washed with a mixture of $0.2 \mathrm{~mol} / \mathrm{L}$ saccharose $/ 0.1 \mathrm{~mol} / \mathrm{L}$ sodium cacodylate. We then postfixed cells for $1 \mathrm{~h}$ with $1 \% \mathrm{OsO} 4$ diluted in $0.2 \mathrm{~mol} / \mathrm{L}$ potassium hexacyanoferrate (III) $/ 0.1$ $\mathrm{mol} / \mathrm{L}$ sodium cacodylate solution. After washing the cells with distilled water, we gradually dehydrated them with ethanol, then gradually replaced the ethanol with LR white resin. We performed polymerization for $24 \mathrm{~h}$ at $60^{\circ} \mathrm{C}$. We obtained ultrathin, 70-nm sections by using a UC7 


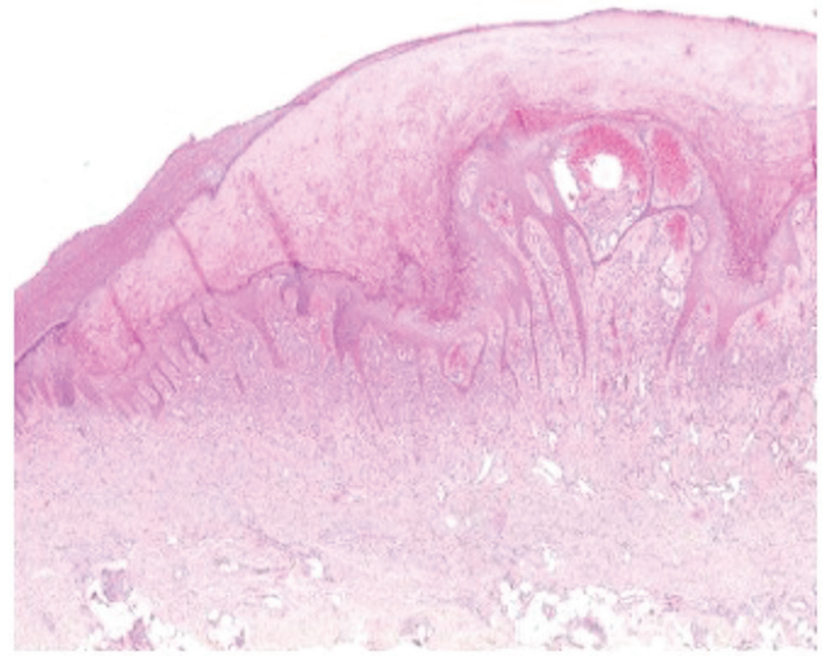

Figure 2. Histopathologic analysis of a skin biopsy specimen from a 65-year-old woman infected with orf virus during Aïdel-Fitr festival, France, 2017. The specimen shows epidermal hyperplasia with acantolysis and papillomatosis, extensive hyperkeratosis, spongiform degeneration and vacuolated cells, and inflammatory infiltration in the dermis, predominantly by histiocytes and lymphocytes. Hematoxylin and eosin stain, original magnification $\times 100$.

ultramicrotome (Leica, https://www.leica-microsystems. com) and placed the sections onto HR25 300-mesh copper/rhodium grids (TAAB, https://www.taab.co.uk). We colored the sections with Reynolds solution. We obtained electron micrographs by using a Tecnai G2 transmission electron microscope (FEI, https://www.fei.com) operated at $200 \mathrm{keV}$ and used ImageJ software (https://imagej.nih. gov) to determine particle size.

\section{Genome Sequencing and Assembling}

We sequenced genomic DNA of the parapoxvirus by using MiSeq Technology (Illumina, https://www.illumina.com) and the paired-end strategy. We barcoded sequences and compared them with 19 other genomic projects prepared from Nextera XT DNA Sample Prep Kit (Illumina). We quantified genomic DNA by using the Qubit Assay and the High-Sensitivity Kit (Life Technologies, https://www. thermofisher.com) at a concentration of $43 \mathrm{ng} / \mu \mathrm{L}$. To prepare the paired-end library, we performed a dilution to obtain $1 \mathrm{ng}$ of each genome as input to prepare the paired-end library. The tagmentation step (Illumina) fragmented and tagged the DNA. Limited cycle PCR amplification (12 cycles) completed the tag adapters and introduced dual-index barcodes. After purification by using AMPure XP Beads (Beckman Coulter Inc., https://www.beckmancoulter. com), we normalized the libraries on specific beads according to the Nextera XT protocol (Illumina). We pooled normalized libraries into a single library for sequencing, then loaded the pooled single-strand library onto the reagent cartridge and then onto the instrument along with the flow cell. We performed automated cluster generation and paired-end sequencing with dual index reads in a single 39 -h run for $2 \times 250 \mathrm{bp}$.

We obtained total information of $10.2 \mathrm{~Gb}$ from $1,140,000$ clusters of density $/ \mathrm{mm}^{2}$ and established a cluster passing quality control filters at $91.2 \%(19,783,000$ clusters). Within this run, we determined the index representation for the parapoxvirus to be $5.45 \%$. We filtered the $1,078,648$ paired-end reads according to the read qualities.

We assembled paired-end reads by using the Hybrid spades program (17) and only paired-end strategy in input. We obtained 1 contig of 132,823 bp with an average coverage of $190 \mathrm{reads} / \mathrm{base}$.

\section{Gene Prediction and Analysis}

We used Prodigal software for gene prediction (18). For predicted proteins that had lengths $<100$ amino acids, we used Phyre 2 software to predict the tridimensional fold (19). For the 130 initial predicted proteins, we deleted 4 predicted proteins with abnormal folds. We performed a blastp analysis (https://blast.ncbi.nlm.nih.gov/Blast. cgi?PAGE=Proteins\&) of all predicted proteins against the nonredundant database at the National Center for Biotechnology Information (https://www.ncbi.nlm.nih.gov) and performed annotation by using delta-blastp results (20) and Interproscan version 69.0 (https://www.ebi.ac.uk). To determine average nucleotide values, we compared close phylogenetic strains by using the OrthoANI algorithm (21); we compared predicted proteins by using the reciprocal best hit and ProteinOrtho software (22) with $80 \%$ coverage, $20 \%$ identity, and $10^{-2}$ as an E value cutoff. The genome is available in the EMBL-EBI database (https://www.ebi. ac.uk, accession no. LR594616).

\section{Phylogenetic Analysis}

We performed alignment of 22 complete genomes of parapoxviruses with a closely related squirrel poxvirus, by using molluscum contagiosum virus as an outgroup. We computed alignments by using MAFFT version 7 (23) with fast Fourier transformation, a heuristic progressive method, and manually controlled alignments in MEGA6.0 (https:// www.megasoftware.net) to delete inverted repeat regions nonaligned at both ends. We conserved 208,216 positions to build a tree by using the general time-reversible model on the PhyML version 3 program (24) and visualized trees by using the iTol online program (25).

\section{Results}

\section{Virus Isolation and Ultrastructure}

The cutaneous biopsy specimen from the patient was found to contain parapoxvirus, which was confirmed by using 
a quantitative PCR. We inoculated this biopsy specimen onto OA3.Ts cells, and monitored lysis daily by using an inverted microscope. We detected a cytopathic effect at 48 $\mathrm{h}$ postinfection. Electron microscopy confirmed the presence of virions in cells at $24 \mathrm{~h}$ after reculture and by observations of ultrathin sections (Figure 3).

\section{Characterization of Orf Virus Genome}

We obtained a linear complete genome of $132,823 \mathrm{bp}$ with a guanine cytosine-rich content of $\approx 64.4 \%$. This genome is the third smallest by length among parapoxviruses, after orf virus strain NP and seal parapoxvirus (Table). We propose to name this orf virus strain IHUMI-1.

Genome organization of orthopoxviruses are known to be conserved and follow the typical structure with inverted terminal repeat variations and a conserved central core genome $(33,34)$. This structure was also suggested for parapoxviruses (35). We investigated synteny by using current complete genome reports. Mauve analysis of $12 \mathrm{com}-$ plete genomes of orf virus enabled us to observe intraspecies conservation, except at the ends of some genomes (Appendix Figure 1, https://wwwnc.cdc.gov/EID/article/25/12/181513-App1.pdf). Moreover, analysis of synteny blocks across parapoxviruses showed the same typical organization (Appendix Figure 2). By using blast and MEGA analysis of the complete genome of orf virus IHUMI-1, we observed matches with all orf virus genomes, a squirrelpox virus genome, and a molluscum contagiosum virus genome $(15 \%$ coverage and $80 \%$ identity). This region between the orf genome and molluscum contagiosum virus genome of $\approx 3,500$ nt (positions on orf virus IHUMI-1 from 97,602 to 101,032) encodes a predicted protein essential for viruses: DNA-directed RNA polymerase subunit RPO132 ( $R b p 2)$.

Focusing on the 126 predicted proteins of virus strain IHUMI-1, we observed 124 best hits with different strains of orf virus, 1 hit with a hypothetical protein with Mucor circinelloides (with an E value of $10^{-3}$ ), and 1 hit with Ovis aries sheep, the natural host. The protein showing the best hit with $O$. aries sheep was annotated as the interleukin- 10 precursor. The gene for this protein is found in parapoxvirus and was probably acquired from mammals and known as a potential keystone protein that reduces inflammation during the infectious cycle (36-39). Despite the position of this gene at the left start region of genomes of parapoxviruses, this protein is highly conserved. The interleukin- 10 gene of orf virus IHUMI-1 shows $99 \%$ nucleotide sequence identity with other orf virus strains and $79 \%$ with $O$. aries sheep and with Capra hircus goats; the gene showed, as reported, numerous synonymous mutations and adaptations by orf virus (39).
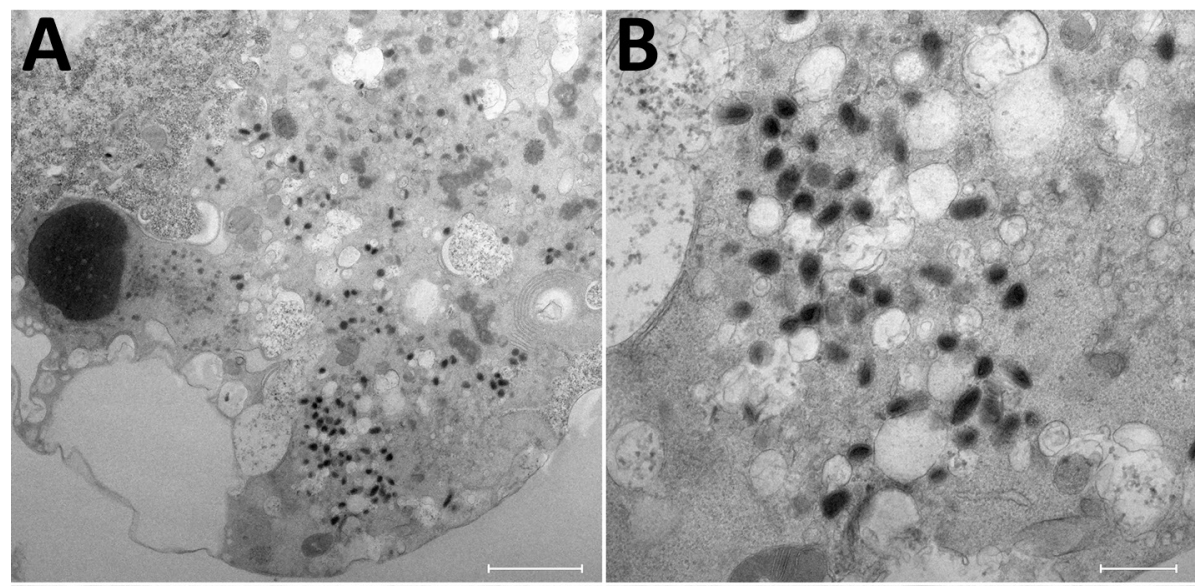

Figure 3. Transmission electron microscopy of OAT3.T cells infected with orf virus IHUMI-1 from a 65-yearold woman in France. A) Ultrathin section of an OAT3.Ts cell at $24 \mathrm{~h}$ postinfection harboring orf virus strain IHUMI-1 undergoing its replicative cycle where dense inclusion bodies could be clearly seen in the cell cytoplasm. B, C) Higher magnifications of infected cells showing typical enveloped virions. D) Ultrathin sections of an OAT3.Ts cell showing enveloped particles (arrows). Scale bars indicate $2 \mu \mathrm{m}$ in panel A, $50 \mathrm{~nm}$
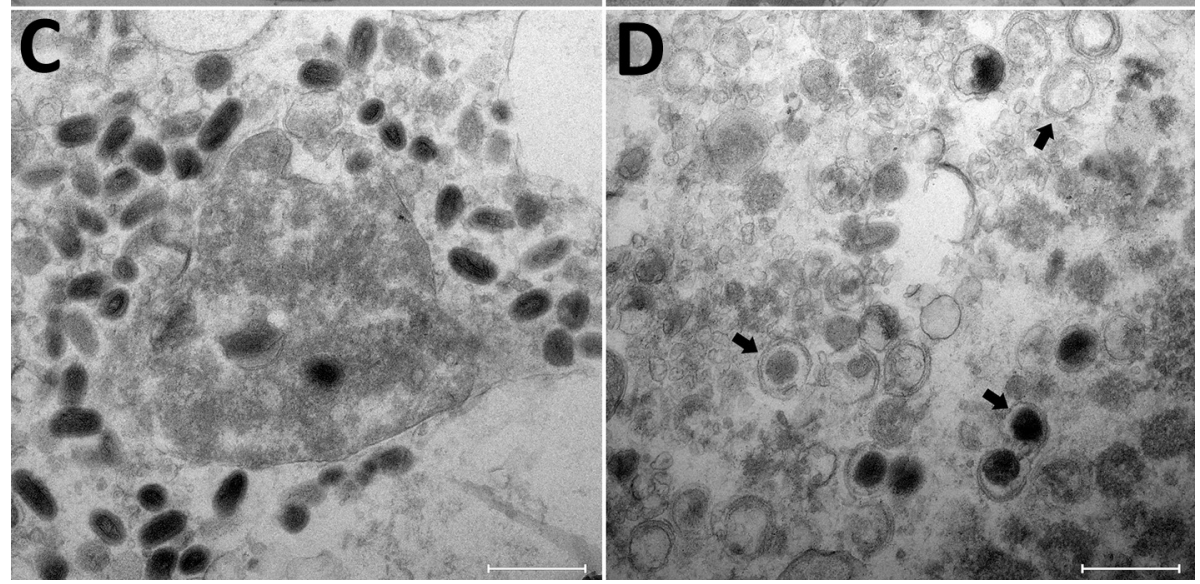
in panels $B, C$, and $D$. 
Table. Genomic characteristics of parapoxviruses used for analysis of an orf virus isolated from a 65-year-old woman infected during Aid-el-Fïtr, festival, France, 2017

\begin{tabular}{|c|c|c|c|c|}
\hline Virus & $\begin{array}{l}\text { Genome } \\
\text { length, bp }\end{array}$ & $\begin{array}{c}\text { GenBank } \\
\text { accession no. }\end{array}$ & Source of virus & Reference \\
\hline Orf virus strain PACA France 2017 & 132,823 & LR594616 & $\begin{array}{l}\text { Hand nodule from human: } 2017, \\
\text { France }\end{array}$ & This study \\
\hline Orf virus strain OV-IA82 & 137,241 & AY386263.1 & Nasal secretion from lamb: 1982, lowa & (15) \\
\hline Orf virus strain NZ2 & 137,820 & DQ184476.1 & Sheep: New Zealand & (26) \\
\hline Orf virus strain B029 & 134,104 & KF837136.1 & Human: Germany 1996 & (14) \\
\hline Orf virus strain OV-HN3/12 & 136,643 & KY053526.1 & Sheep: China 2012 & (27) \\
\hline Orf virus strain NA1/11 & 137,080 & KF234407.1 & Sheep: China 2011 & (27) \\
\hline Orf virus strain GO & 139,866 & KP010354.1 & Lamb: Fujian, China, 2012 & (27) \\
\hline Orf virus strain D1701 & 134,038 & HM133903.1 & Sheep: Germany & (28) \\
\hline Orf virus strain SJ1 & 139,112 & KP010356.1 & Lamb: Fujian, China, 2012 & (27) \\
\hline Orf virus strain $\mathrm{YX}$ & 138,231 & KP010353.1 & Lamb: Fujian, China, 2012 & (27) \\
\hline Orf virus strain OV-SA00 & 139,962 & AY386264.1 & Goat kid: 2010 , Texas & (15) \\
\hline Orf virus strain NP & 132,111 & KP010355.1 & Lamb: Fujian, China, 2011 & (27) \\
\hline Pseudocowpox virus strain VR634 & 145,289 & GQ329670.1 & $\begin{array}{l}\text { Human after contact with } \\
\text { contaminated cow: } 1963 \text {, USA }\end{array}$ & $(29)$ \\
\hline Pseudocowpox virus strain F00.120R & 133,169 & GQ329669.1 & Reindeer: Finland, 2009 & (29) \\
\hline Bovine papular stomatitis virus strain BV-TX09c1 & 135,072 & KM875472.1 & Domestic cow: 2009, USA & (30) \\
\hline Bovine papular stomatitis virus strain BV-TX09c15 & 136,055 & KM875470.1 & Domestic cow: 2009, USA & (30) \\
\hline Bovine papular stomatitis virus strain BV-TX09c5 & 135,635 & KM875471.1 & Domestic cow: 2009, USA & (30) \\
\hline Bovine papular stomatitis virus strain BV-AR02 & 134,431 & AY386265.1 & Calf (oral lesions): Arkansas, 2004? & (15) \\
\hline Parapoxvirus red deer/HL953 & 139,981 & KM502564.1 & $\begin{array}{c}\text { Red deer (tonsil swab): Germany, } \\
2013 \text {, subclinical infection }\end{array}$ & $(31)$ \\
\hline Seal parapoxvirus isolate AFK76s1 & 127,941 & KY382358.2 & Gray seal: Poland, 2015 & (1) \\
\hline Squirrel poxvirus strain red squirrel UK & 148,803 & HE601899.1 & $\begin{array}{c}\text { Red squirrel, UK: } 2014 \text {, outgroup of } \\
\text { parapoxvirus }\end{array}$ & (32) \\
\hline
\end{tabular}

\section{Virus Clusters and Distribution}

Orthopoxviruses, such as various strains of cowpox virus, circulate in Europe, and clusters are well identified with clades and subclades $(40,41)$. Concerning parapoxviruses, a previous study of whole genomes of orf viruses showed that clusters exist and depend on whether the host is a goat or a sheep (27). Our phylogenetic analysis performed on whole genomes of parapoxviruses, which used the maximum-likelihood method, identified clusters with 2 different branches of orf viruses that had a common ancestor. This result is similar to that of Chi et al. (27) and showed 2 branches depending on whether the virus host was a goat or a sheep (Figure 4). In contrast, analysis by using the OrthoANi algorithm enabled us to separate orf viruses that originated

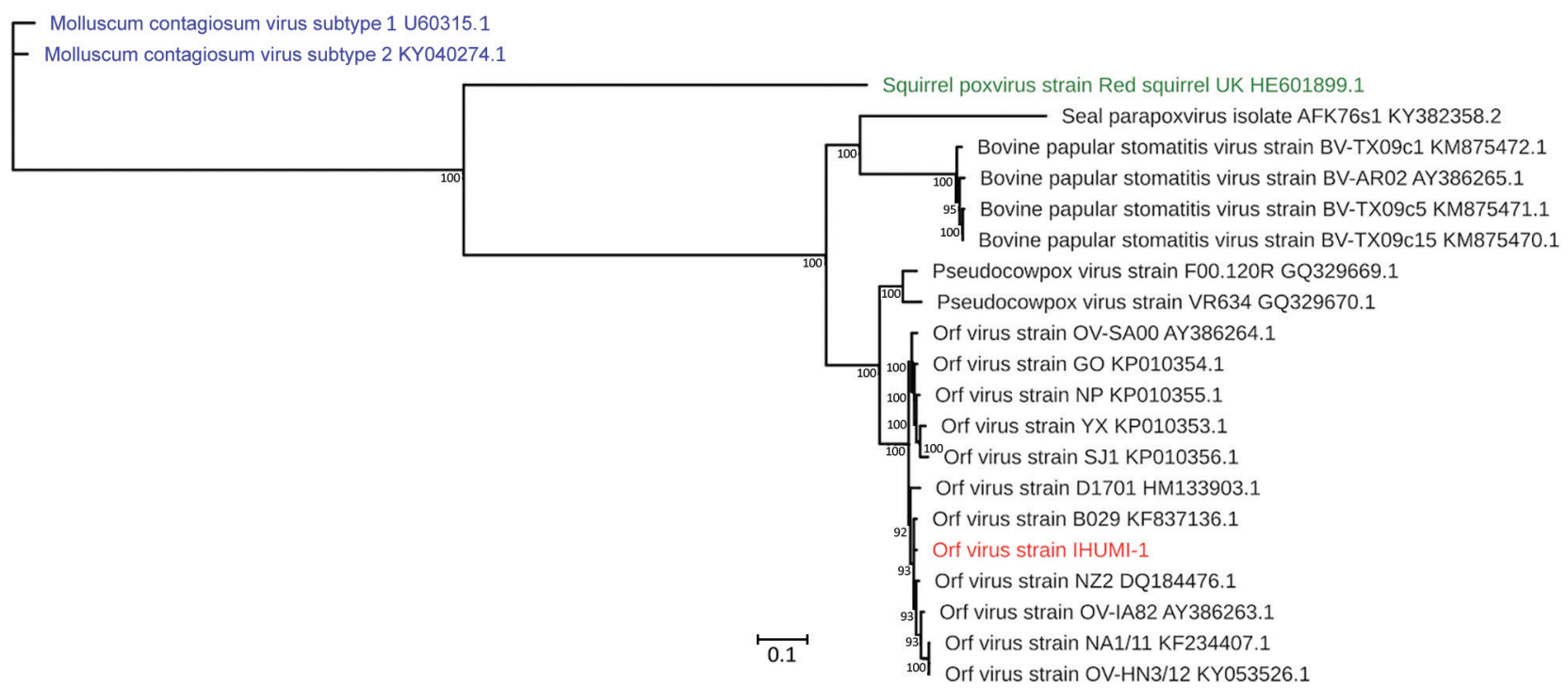

Figure 4. Maximum-likelihood tree based on complete sequences of orf virus IHUMI-1 from a 65-year-old woman in France (red) and 22 other viruses belonging to the family Poxviridae. Tree was constructed by using a general time-reversible model with 100 bootstrap replicates. All branches with bootstrap values $<70$ were collapsed. Numbers along branches are bootstrap values. Blue indicates 2 chordopoxviruses that served as outgroups, and green indicates a squirrel poxvirus still unclassified but related to the genus Parapoxvirus. GenBank accession numbers are provided for reference isolates. Scale bar indicates nucleotide substitutions per site. 
from sheep and those that originated from goats (Figure 5). The only difference we observed was for orf virus strain D1701, which appeared to be an outgroup strain. Nevertheless, when we used the maximum-likelihood method and the OrthoANi algorithm, we found that orf virus IHUMI-1 clustered with orf virus strain B029. These 2 strains were human isolates obtained after infection from sheep.

Reciprocal best hit analysis enabled us to observe a high degree of conservation across orf virus genomes. A total of 102 proteins composed the core genomes of 12 orf viruses, and we did not detect any differences in core genomes of orf virus clusters. All virus proteins known to be essential (e.g., vascular endothelial growth factor, interleukin-10, and nuclear factor- $\kappa \mathrm{B}$ inhibitor protein) $(39,42,43)$ are present in the genome of orf virus strain IHUMI-1.

Protein analysis showed an absence of a predicted homolog open reading frame 119 in orf virus IHUMI-1. For his region, Chi et al. (27) reported numerous deletions and gap sequences (Appendix Figure 3), especially for 3 strains (NP, SJ1, and IHUMI-1). Coverage was $<80 \%$ in that region for strains SJ1 and IHUMI-1, and the gene was almost completely deleted for strain NP (only $24 \%$ coverage) compared with strain OV-SA00. The consequence for orf virus IHUMI-1 is the deletion of the ORF119 gene.
This deletion has been implied in cell apoptosis $(44,45)$. Nevertheless, deletion of this gene did not affect the virus cycle and strain virulence (46).

\section{Discussion}

We determined the complete genome of orf virus strain IHUMI-1 isolated from a human. This virus is the third smallest (by genome length) in the genus Parapoxvirus. The genome organization of orf virus IHUMI-1 is extremely similar in its synteny with those of other orf viruses that do not have a genetic inversion. Analysis of the predicted protein highlights strong protein conservation, except for the deletion in the ORF119 gene. The mitochondrial protein coded by this gene was recently described as being capable of increasing cell apoptosis $(44,45)$. Despite this finding, our observations and a previous report showed no phenotypic modification in the virus cycle regarding this gene deletion (46).

Conversely, phylogenetic analysis of the entire virus genome showed clustering of orf viruses depending on the host (sheep or goats). This result was similar to those of previous analyses performed on different complete genomes by Chi et al. (27). Some studies did not report similar results; however, the phylogenetic trees in those studies

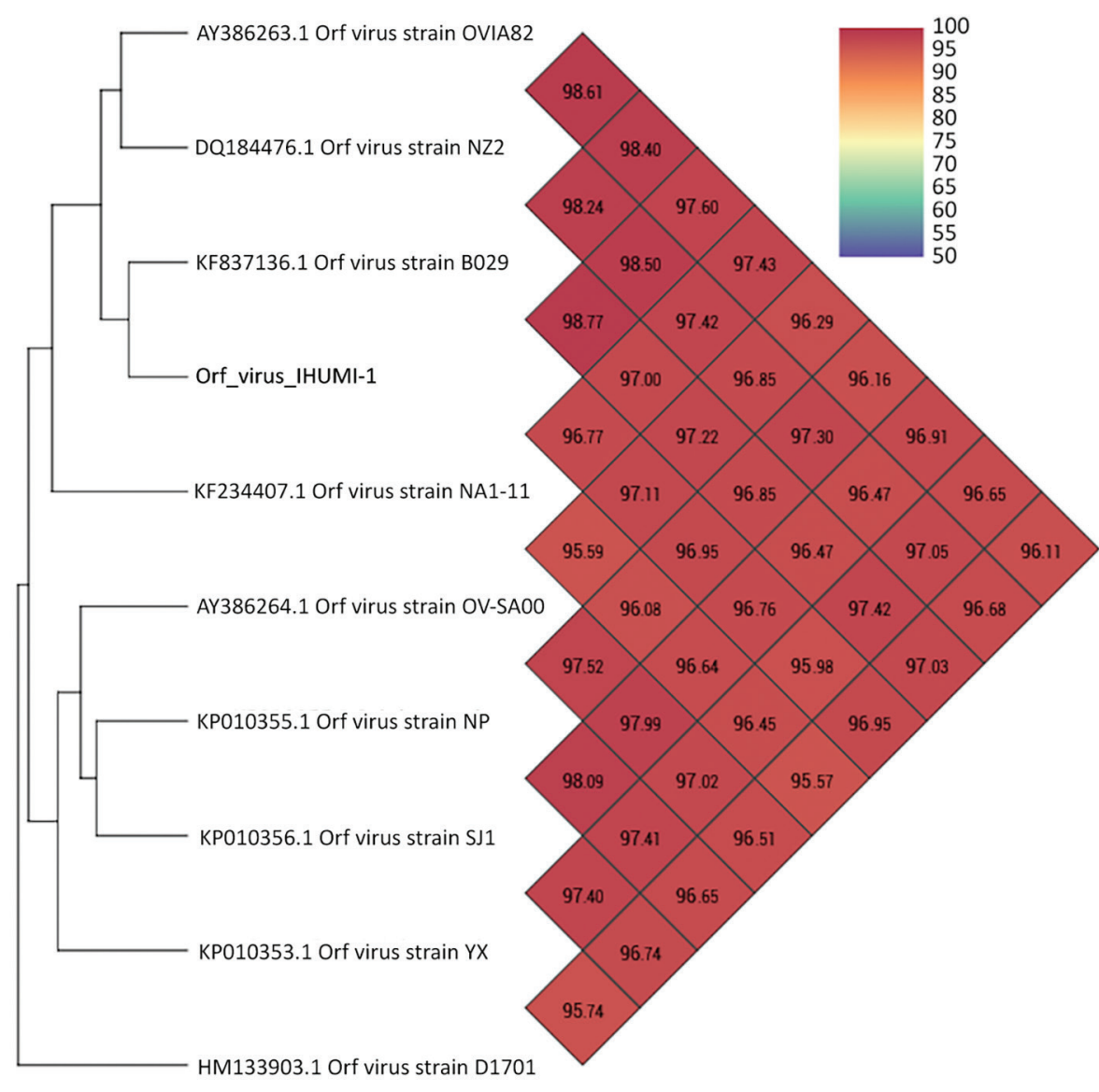

Figure 5. Heatmap representation of strain proximities across complete genomes of orf virus IHUMI-1 from a 65-year-old woman in France (red) and other available orf viruses. Because of the OrthoANi algorithm constraint, we deleted the complete genome of orf virus strain GO (GenBank accession no. KP010354.1) that clusters with orf virus strain NP and the complete genome of orf virus strain OV-HN3/12 (that clusters with NA1-11). GenBank accession numbers are provided for reference isolates. Values indicate percent similarity of nucleotides. 
were limited to analysis of a few genes, such as the partial B2L gene (47-49). More complete genomes are needed to confirm this trend and verify there are 2 types of orf virus. In addition, we observed clustering on the whole genome between the IHUMI-1 and B029 strains of orf virus after human infection. Further investigations using more complete genome sequences might be able to confirm if some genetically related strains have the potential capacity to cross species barriers.

Numerous strains of parapoxviruses that infect animals are believed to show variable virulence in humans (e.g., orf strain D1701). However, implication of the host immune system in the severity of orf virus disease and in its evolution have been demonstrated (50).

Our results highlight the necessity of obtaining more complete genomes for parapoxviruses and retracing the route of infection when humans are infected. Further investigations of parapoxviruses should address the difficulties in isolating and cultivating this fastidious virus by using nonconventional cells for diagnostic analysis. However, recent description of a seal parapoxvirus (1) with a highquality genome sequence obtained directly from a clinical sample could bypass the culture problem. In contrast, isolating the viral particle will always help to improve clinical research and future innovations.

This study was supported by a grant from the French government under the Investissements d'Avenir Program managed by the Agence Nationale de la Recherche (Méditerranée Infection 10-IAHU-03).

\section{About the Author}

Mr. Andreani is a PharmD-PhD student in the Institut National de la Santé et de la Recherche Médicale program at Aix-Marseille University, Marseille, France. His research interests include isolation and genomic characterization of large and giant DNA viruses.

\section{References}

1. Günther T, Haas L, Alawi M, Wohlsein P, Marks J, Grundhoff A, et al. Recovery of the first full-length genome sequence of a parapoxvirus directly from a clinical sample. Sci Rep. 2017;7:3734. https://doi.org/10.1038/s41598-017-03997-y

2. Leavell UW Jr, McNamara MJ, Muelling R, Talbert WM, Rucker RC, Dalton AJ. Orf: report of 19 human cases with clinical and pathological observations. JAMA. 1968;204:657-64. https://doi.org/10.1001/jama.1968.03140210011003

3. Johannessen JV, Krogh HK, Solberg I, Dalen A, van Wijngaarden H, Johansen B. Human orf. J Cutan Pathol. 1975;2:265-83. https://doi.org/10.1111/j.1600-0560.1975.tb00179.x

4. Nougairede A, Fossati C, Salez N, Cohen-Bacrie S, Ninove L, Michel F, et al. Sheep-to-human transmission of Orf virus during Eid al-Adha religious practices, France. Emerg Infect Dis. 2013;19:102-5. https://doi.org/10.3201/eid1901.120421

5. Ginzburg VE, Liauchonak I. Human orf: atypical rash in an urban medical practice. Can Fam Physician. 2017;63:769-71.
6. Lederman ER, Green GM, DeGroot HE, Dahl P, Goldman E, Greer PW, et al. Progressive ORF virus infection in a patient with lymphoma: successful treatment using imiquimod. Clin Infect Dis. 2007;44:e100-3. https://doi.org/10.1086/517509

7. Hasheminasab SS, Mahmoodi A, Mahmoodi P, Maghsood H. Orf virus infection in human ecthyma contagiosum: a report of two cases in the West of Iran. Virusdisease. 2016;27:209-10. https://doi.org/10.1007/s13337-016-0304-1

8. Abrahão JS, Silva-Fernandes AT, Assis FL, Guedes MI, Drumond BP, Leite JA, et al. Human vaccinia virus and pseudocowpox virus co-infection: clinical description and phylogenetic characterization. J Clin Virol. 2010;48:69-72. https://doi.org/10.1016/j.jcv.2010.02.001

9. Oğuzoğlu TÇ, Koç BT, Kirdeci A, Tan MT. Evidence of zoonotic pseudocowpox virus infection from a cattle in Turkey. Virusdisease. 2014;25:381-4. https://doi.org/10.1007/s13337-014-0214-z

10. Malik M, Bharier M, Tahan S, Robinson-Bostom L. Orf acquired during religious observance. Arch Dermatol. 2009;145:606-8. https://doi.org/10.1001/archdermatol.2009.69

11. Turk BG, Senturk B, Dereli T, Yaman B. A rare human-tohuman transmission of orf. Int J Dermatol. 2014;53:e63-5. https://doi.org/10.1111/j.1365-4632.2012.05669.x

12. Rajkomar V, Hannah M, Coulson IH, Owen CM. A case of human to human transmission of orf between mother and child. Clin Exp Dermatol. 2016;41:60-3. https://doi.org/10.1111/ced.12697

13. Bala JA, Balakrishnan KN, Abdullah AA, Mohamed R, Haron AW, Jesse FFA, et al. The re-emerging of orf virus infection: a call for surveillance, vaccination and effective control measures. Microb Pathog. 2018;120:55-63. https://doi.org/10.1016/ j.micpath.2018.04.057

14. Friederichs S, Krebs S, Blum H, Wolf E, Lang H, von Buttlar H, et al. Comparative and retrospective molecular analysis of parapoxvirus (PPV) isolates. Virus Res. 2014;181:11-21. https://doi.org/10.1016/j.virusres.2013.12.015

15. Delhon G, Tulman ER, Afonso CL, Lu Z, de la Concha-Bermejillo A, Lehmkuhl HD, et al. Genomes of the parapoxviruses orf virus and bovine papular stomatitis virus. J Virol. 2004;78:168-77. https://doi.org/10.1128/JVI.78.1.168-177.2004

16. Bou Khalil JY, Benamar S, Di Pinto F, Blanc-Tailleur C, Raoult D, La Scola B. Protochlamydia phocaeensis sp. nov., a new Chlamydiales species with host dependent replication cycle. Microbes Infect. 2017;19:343-50. https://doi.org/10.1016/ j.micinf.2017.02.003

17. Antipov D, Korobeynikov A, McLean JS, Pevzner PA. hybridSPAdes: an algorithm for hybrid assembly of short and long reads. Bioinformatics. 2016;32:1009-15. https://doi.org/10.1093/ bioinformatics/btv688

18. Hyatt D, Chen G-L, Locascio PF, Land ML, Larimer FW, Hauser LJ. Prodigal: prokaryotic gene recognition and translation initiation site identification. BMC Bioinformatics. 2010;11:119. https://doi.org/10.1186/1471-2105-11-119

19. Kelley LA, Mezulis S, Yates CM, Wass MN, Sternberg MJ. The Phyre2 web portal for protein modeling, prediction and analysis. Nat Protoc. 2015;10:845-58. https://doi.org/10.1038/ nprot.2015.053

20. Boratyn GM, Schäffer AA, Agarwala R, Altschul SF, Lipman DJ, Madden TL. Domain enhanced lookup time accelerated BLAST. Biol Direct. 2012;7:12. https://doi.org/10.1186/1745-6150-7-12

21. Lee I, Ouk Kim Y, Park SC, Chun J. OrthoANI: An improved algorithm and software for calculating average nucleotide identity. Int J Syst Evol Microbiol. 2016;66:1100-3. https://doi.org/10.1099/ ijsem.0.000760

22. Lechner M, Findeiss S, Steiner L, Marz M, Stadler PF, Prohaska SJ. Proteinortho: detection of (co-)orthologs in large-scale analysis. BMC Bioinformatics. 2011;12:124. https://doi.org/10.1186/1471-2105-12-124 
23. Katoh K, Misawa K, Kuma K, Miyata T. MAFFT: a novel method for rapid multiple sequence alignment based on fast Fourier transform. Nucleic Acids Res. 2002;30:3059-66. https://doi.org/ 10.1093/nar/gkf436

24. Guindon S, Gascuel O. A simple, fast, and accurate algorithm to estimate large phylogenies by maximum likelihood. Syst Biol. 2003;52:696-704. https://doi.org/10.1080/ 10635150390235520

25. Letunic I, Bork P. Interactive tree of life (iTOL) v3: an online tool for the display and annotation of phylogenetic and other trees. Nucleic Acids Res. 2016;44:W242-5. https://doi.org/10.1093/nar/ gkw290

26. Mercer AA, Ueda N, Friederichs S-M, Hofmann K, Fraser KM, Bateman T, et al. Comparative analysis of genome sequences of three isolates of Orf virus reveals unexpected sequence variation. Virus Res. 2006;116:146-58. https://doi.org/10.1016/ j.virusres.2005.09.011

27. Chi X, Zeng X, Li W, Hao W, Li M, Huang X, et al. Genome analysis of orf virus isolates from goats in the Fujian Province of southern China. Front Microbiol. 2015;6:1135. https://doi.org/ 10.3389/fmicb.2015.01135

28. McGuire MJ, Johnston SA, Sykes KF. Novel immune-modulator identified by a rapid, functional screen of the parapoxvirus ovis (Orf virus) genome. Proteome Sci. 2012;10:4. https://doi.org/ 10.1186/1477-5956-10-4

29. Hautaniemi M, Ueda N, Tuimala J, Mercer AA, Lahdenperä J, McInnes CJ. The genome of pseudocowpoxvirus: comparison of a reindeer isolate and a reference strain. J Gen Virol. 2010; 91:1560-76. https://doi.org/10.1099/vir.0.018374-0

30. Huang T, Tulman ER, Diel DG, Khatiwada S, Sims W, Edwards JF, et al. Coinfection with multiple strains of bovine papular stomatitis virus. Arch Virol. 2015;160:1527-32. https://doi.org/10.1007/ s00705-015-2394-2

31. Friederichs S, Krebs S, Blum H, Lang H, Büttner M. Parapoxvirus (PPV) of red deer reveals subclinical infection and confirms a unique species. J Gen Virol. 2015;96:1446-62. https://doi.org/10.1099/vir.0.000080

32. McInnes CJ, Wood AR, Thomas K, Sainsbury AW, Gurnell J, Dein FJ, et al. Genomic characterization of a novel poxvirus contributing to the decline of the red squirrel (Sciurus vulgaris) in the UK. J Gen Virol. 2006;87:2115-25. https://doi.org/10.1099/ vir.0.81966-0

33. Mackett M, Archard LC. Conservation and variation in orthopoxvirus genome structure. J Gen Virol. 1979;45:683-701. https://doi.org/10.1099/0022-1317-45-3-683

34. Babkin IV, Babkina IN. The origin of the variola virus. Viruses. 2015;7:1100-12. https://doi.org/10.3390/v7031100

35. Fleming SB, Blok J, Fraser KM, Mercer AA, Robinson AJ. Conservation of gene structure and arrangement between vaccinia virus and orf virus. Virology. 1993;195:175-84. https://doi.org/10.1006/viro.1993.1358

36. Fleming SB, Haig DM, Nettleton P, Reid HW, McCaughan CA, Wise LM, et al. Sequence and functional analysis of a homolog of interleukin-10 encoded by the parapoxvirus orf virus. Virus Genes. 2000;21:85-95. https://doi.org/10.1023/B:VIRU.0000018443. 19040.99

37. Fleming SB, Anderson IE, Thomson J, Deane DL, McInnes CJ, McCaughan CA, et al. Infection with recombinant orf viruses demonstrates that the viral interleukin-10 is a virulence factor. J Gen Virol. 2007;88:1922-7. https://doi.org/10.1099/vir.0.82833-0

38. Bennett JR, Lateef Z, Fleming SB, Mercer AA, Wise LM. Orf virus IL-10 reduces monocyte, dendritic cell and mast cell recruitment to inflamed skin. Virus Res. 2016;213:230-7. https://doi.org/10.1016/j.virusres.2015.12.015

39. Fleming SB, Wise LM, Mercer AA. Molecular genetic analysis of orf virus: a poxvirus that has adapted to skin. Viruses. 2015; 7:1505-39. https://doi.org/10.3390/v7031505

40. Mauldin MR, Antwerpen M, Emerson GL, Li Y, Zoeller G, Carroll DS, et al. Cowpox virus: what's in a name? Viruses. 2017;9:E101. https://doi.org/10.3390/v9050101

41. Franke A, Pfaff F, Jenckel M, Hoffmann B, Höper D, Antwerpen M, et al. Classification of cowpox viruses into several distinct clades and identification of a novel lineage. Viruses. 2017;9:142. https://doi.org/10.3390/v9060142

42. Diel DG, Luo S, Delhon G, Peng Y, Flores EF, Rock DL. Orf virus ORFV121 encodes a novel inhibitor of NF-kappaB that contributes to virus virulence. J Virol. 2011;85:2037-49. https://doi.org/10.1128/JVI.02236-10

43. Mercer AA, Wise LM, Scagliarini A, McInnes CJ, Büttner M, Rziha HJ, et al. Vascular endothelial growth factors encoded by Orf virus show surprising sequence variation but have a conserved, functionally relevant structure. J Gen Virol. 2002;83:2845-55. https://doi.org/10.1099/0022-1317-83-11-2845

44. Nagendraprabhu P, Khatiwada S, Chaulagain S, Delhon G, Rock DL. A parapoxviral virion protein targets the retinoblastoma protein to inhibit NF- $\mathrm{kB}$ signaling. PLoS Pathog. 2017; 13:e1006779. https://doi.org/10.1371/journal.ppat.1006779

45. Li W, Chen H, Deng H, Kuang Z, Long M, Chen D, et al. Orf virus encoded protein ORFV119 induces cell apoptosis through the extrinsic and intrinsic pathways. Front Microbiol. 2018;9:1056. https://doi.org/10.3389/fmicb.2018.01056

46. Qiao J, Yang HB, Peng YL, Meng QL, Chen C, Ma Y, et al. Effect of ORF119 gene deletion on the replication and virulence of orf virus. Acta Virol. 2015;59:257-64. https://doi.org/10.4149/ av_2015_03_257

47. Billinis $\overline{\mathrm{C}}$, Mavrogianni VS, Spyrou V, Fthenakis GC. Phylogenetic analysis of strains of Orf virus isolated from two outbreaks of the disease in sheep in Greece. Virol J. 2012;9:24. https://doi.org/10.1186/1743-422X-9-24

48. Velazquez-Salinas L, Ramirez-Medina E, Bracht AJ, Hole K, Brito BP, Gladue DP, et al. Phylodynamics of Parapoxvirus genus in Mexico (2007-2011). Infect Genet Evol. 2018;65:12-4. https://doi.org/10.1016/j.meegid.2018.07.005

49. Peralta A, Robles CA, Micheluod JF, Rossanigo CE, Martinez A, Carosio A, et al. Phylogenetic analysis of ORF viruses from five contagious ecthyma outbreaks in Argentinian goats. Front Vet Sci. 2018;5:134. https://doi.org/10.3389/fvets.2018.00134

50. de Oliveira CH, Assis FL, Neto JD, Oliveira CM, Lopes CT, Bomjardim HA, et al. Multifocal cutaneous orf virus infection in goats in the Amazon region, Brazil. Vector Borne Zoonotic Dis. 2012;12:336-40. https://doi.org/10.1089/vbz.2011.0725

Address for correspondence: Bernard La Scola, Aix Marseille Université, Institut Hospitalo-Universitaire Méditerranée Infection, 19-21 Bd Jean Moulin, 13005 Marseille, France; email: bernard.la-scola@univ-amu.fr 